\title{
(息)
}

Citation:

Spracklen, $\mathrm{K}$ and Long, $\mathrm{J}$ and Hylton, $\mathrm{K}$ (2014) Leisure opportunities and new migrant communities: challenging the contribution of sport. Leisure Studies, 34 (1). 114 - 129. ISSN 0261-4367 DOI: https://doi.org/10.1080/02614367.2014.939989

Link to Leeds Beckett Repository record:

https://eprints.leedsbeckett.ac.uk/id/eprint/68/

Document Version:

Article (Accepted Version)

The aim of the Leeds Beckett Repository is to provide open access to our research, as required by funder policies and permitted by publishers and copyright law.

The Leeds Beckett repository holds a wide range of publications, each of which has been checked for copyright and the relevant embargo period has been applied by the Research Services team.

We operate on a standard take-down policy. If you are the author or publisher of an output and you would like it removed from the repository, please contact us and we will investigate on a case-by-case basis.

Each thesis in the repository has been cleared where necessary by the author for third party copyright. If you would like a thesis to be removed from the repository or believe there is an issue with copyright, please contact us on openaccess@leedsbeckett.ac.uk and we will investigate on a case-by-case basis. 


\section{Leisure Opportunities and New Migrant Communities: Challenging the Contribution of}

Sport

\section{Introduction}

Everybody needs leisure, and everybody does leisure. But the leisure lives of New Migrant Communities are diminished by the ways in which the instrumental powers in their new homes operate to define, delineate and constrain their leisure (Stodolska, Kimberly, Floyd \& Walker, 2013). Leisure can be a refuge, a source of pleasure, but it can also be something that serves hegemonic interests (Bramham, 2006; Long \& Hylton, 2002; Spracklen, 2009; Watson and Scraton, 2013). It is perhaps a truism to say that as a space and activity in our everyday lives, leisure has been identified as having social and cultural value (Roberts, 2004, 2011; Rojek, 2013; Spracklen, 2009, 2011a, 2011b, 2013). In this journal, Ken Roberts (2011, p. 8) argues:

Leisure scholars have been close to unanimous... that leisure behaviour is at least relatively freely chosen... this is possible because the particular ways in which people choose to spend their leisure time and money are relatively inconsequential, often for the individuals themselves and even more so for their wider societies (beyond the actors' personal social networks). The 'relatively' in freely choosing is in contrast to how most people's behaviour is controlled while they are at work, and relatively inconsequential is in comparison with decisions such as whether to take or to resign from a job, to quit or to continue in education, to marry or to divorce, and whether or not to become a parent... Modern leisure is typically separated from the rest of our lives by some combination of place, time or activity. 
Leisure, then, has value for individuals and communities because it is 'relatively freely chosen'. As individuals, we choose leisure activities and inhabit leisure spaces because these are things that we like to do - or that we think we like to do. Leisure has value for communities because it gives people a sense of belonging and identity. Leisure has this value and importance according to Spracklen (2009, 2011a, 2011b, 2013) because it has a Habermasian communicative rationality at its heart (Habermas, 1984, 1987). Spracklen and Spracklen (2012, p. 351) define communicative rationality as:

... the application of free reason and democratic discourse to the construction of the public sphere, the way in which we discuss and make choices about the things we do in life (such as the sports we play and the books we read, or the parties we vote for), ideally free from constraint: a rationality that constructs what Habermas (1984) calls the lifeworld... leisure and culture [are] places where communicative rationality can produce communicative action: only that to be communicative, there has to be a public (externalised) sphere in which debates about meaning can take place.

In a late modern, possibly liquid modern society, such leisure has enormous potential for bringing people together and making people feel they belong (Blackshaw, 2010). Rojek (2010) has shown how the act of doing leisure makes us do identity work, whether we are playing squash with an acquaintance, having drinks with good friends or liking pages on Facebook. In its communicative form, leisure has the potential to produce inclusive intentionality, expressed in real equality and playful, postmodern identity politics. Leisure could be, and has been described as, a site for the construction of social and cultural capital. Cultural capital is best understood by reference to a Bourdieusian framework of habitus and fields, in which certain individuals and elites control the ways in which taste and distinction 
are defined (Bourdieu, 1984). The OECD definition of social capital refers to 'social networks, norms, values and understandings that facilitate cooperation within or among groups' (OECD 2001, p. 41); those adopting the approach of Putnam (2000) would add 'trust'. Such forms of social capital in leisure might be bonding in nature, creating strong connections within social groups and communities (Guiberneau, 2013); or they may be bridging in nature, bringing different communities and individuals together who otherwise would not have much in common.

In this paper we are interested in the role leisure and sport might play for increasing belonging and inclusion for new migrant communities. The case for sport as a form of bonding and bridging capital for inclusion for minority ethnic groups has been made by many policy-makers and sports sociologists - less so for new migrant communities. In this paper we set out the claims made for the value of sport to critique them, using research data gathered as part of a project mapping the leisure lives and spaces of two new migrant communities in Leeds, UK. Initial findings from the first phase of the project have been published (Long, Hylton, Lewis, Ratna \& Spracklen, 2011), and we have presented findings on the migrant experiences of leisure and exclusion more broadly (Long, 2012). We use new and unpublished data and analysis from our research project on new migrant communities to suggest that sports do not necessarily play an important role in building bridging capital. Sports activities and opportunities do not necessarily follow our new migrant respondents in their transitions into the UK. We argue that leisure in more communicative forms and spaces is important for the respondents in building a sense of belonging within the new migrant communities and the locality, but for most of the respondents, sports do not build, bond or bridge in any meaningful way.

\section{Literature review}


The recent passing of Nelson Mandela was trumpeted by his famous ideas on the power of sport that resonate so well with the functional-pluralism that underscores many approaches to the benefits sport can bring to society. For most involved in sport policy and practice it would be very unusual to hear a case against sport's power for positive change. In many ways national governing organisations that strive to demonstrate the value of sport in relation to integration, inclusion, cohesion, regeneration, economic impacts, health, education, and communities offer insight to their dominant worldview of sport. Though there is some dissent about the depth and quality of the evidence available, the case for sport is a quiet given as diverse proof is sought to make the case more convincingly. Gasparini and Cometti’s (2010) work for the Council of Europe (CoE) articulates this influential stakeholder's view on the potential for sport to facilitate the integration of immigrant and minority ethnic groups across Europe. Though they clearly acknowledge that key terms such as integration are interpreted differently across nations, and that the conditions needed to facilitate positive change are therefore also specific, the case for sport's potential still holds. In introducing Gasparini and Cometti's work, the Executive Secretary of the CoE's Enlarged Partial Agreement on Sport Stan Frossard (2010: 6) stated that:

Indeed, when we speak about "integration through sport", there is wide acknowledgement of the positive contribution sport makes to social integration, for ethnic minorities and immigrant communities in particular.

It is no surprise that many policymakers and practitioners agree with sport's restorative benefits as a torrent of influential sources support this consensus. In addition to national governing organisations of sport, the European Union, and the United Nations, international governing organisations, also concerned with sport for development and peace 
networks, support the view that sport contributes to the development of social capital and social integration (SDP/IWG 2006; United Nations 2005, 2013). Many are active in pursuing social agendas with sport viewed as a central factor for integrating excluded or marginalised communities that range from people with disabilities, women and girls, to migrants, former child combatants and people living with HIV and AIDS. Some speak of the myth of sport's efficacy to achieve social objectives yet it continues to defy challenges to the contrary.

Since the publication of Bowling Alone (Putnam, 2000) sport scholars have seized on the idea of social capital with gusto. It has allowed such scholars to demonstrate a much prized relevance to policy debates. Halpern (2005, p. 3) sees social capital as being about the 'everyday fabric of connection', but that in itself is insufficient to capture a form of capital. The kernel of Putnam's thesis is that by interacting with others, people build their social capital through the development of shared norms and trust. The shared norms and values refer to a recognition of the value of democracy, active citizenship or voluntarism, and the trust (in our context) might stem from sharing inter-cultural knowledge. This social capital takes rather different forms depending upon whether the links are between people who are alike (bonding) or unlike (bridging) in some uncertain way, or with those in a position of power (linking). Separately or collectively this social capital makes society more productive.

Bourdieu (1984) also emphasised the value of social capital, but for him it is deployed by individuals as any other form of capital to place themselves in a position of advantage. For Bourdieu, capitals are resources to be exploited, combined to constitute the categories of distinction which both produce and reproduce social class divisions (being a member of an exclusive golf club, being on the 'right' committee, etc.). Poorer community groups tend to be at the mercy of forces over which they have little control. Yet they tend to be blamed for their own poverty on the basis that they lack social capital. 
While you cannot have social capital independent of a social network, they are not equivalent. Networks do, however, provide access to the resources that constitute social capital (Lin, 2006). At the same time Lin argues that it is not social capital, but social networks that bind or bridge. Lin (2001) identifies the key ways in which the resources of a network represent useful capital: as a source of information; as a way of exerting influence on people; providing social credentials; and reinforcing one's identity. This does not just happen. Initially people have to invest in developing resources which they can subsequently access and put to use in order to reap reward. Lin (2001) also differentiates the purposes that social capital can be put to: expressive (for cohesion, solidarity, or well-being) and instrumental (to get wealth, power, or reputation). Whereas the bonding of new migrants may suffice for the former, they are likely to need to bridge and link to secure the latter.

Our concern in this paper is with the part that sport and leisure might play in contributing to social capital and whether that can be deployed in promoting inclusion. Putnam himself (2000, p. 411) recognised the potential contribution of sport:

To build bridging social capital requires that we transcend our social and political and professional identities to connect with people unlike ourselves. This is why team sports provide good venues for social-capital creation.

Siisiäinen (2000) even went so far as to suggest that it is only really in relation to sport and leisure associations that Putnam's idea of social capital has any purchase. This sporting link has found its way into the policy discourse on community cohesion with, for example, the Denham Report on community cohesion and building shared social capital, concluding that: 
Sporting and cultural opportunities can play an important part in re-engaging disaffected sections of the community, building shared social capital and grass roots leadership through improved cross-cultural interaction. (Denham, 2001, p. 28)

There is now research from around the world that suggests there is evidence to support the idea that sport can build social capital (e.g., Maxwell \& Taylor 2010; Theebom, Schaillée and Nols, 2012; Walseth, 2006, 2008). The study by Maxwell and Taylor (2010) offers an interesting example by examining not just the participants but the practices of the organisation. They recorded the development of social capital in community sports organizations by developing trust, cooperation and a sense of community, suggesting in the process that the participation of Muslim women changed the cultural awareness and practices of Australian sports organisations.

However we are mindful of what Coalter (2010, p. 1386) terms 'overly romanticized, communitarian generalizations'. As people who want to promote the value of sport, we find ourselves in the strange position of having to moderate the expectations of some who now glibly presume that sport will unproblematically deliver social benefits. Inviting agreement from his readers Halpern (2005, p. 322) asks, 'Would a European football team, formed to take on the Americas, help create a more fertile base for European democracy than a bureaucracy in Brussels ever could?' The answer is 'probably not': a) because of the ability for football in such circumstances to foment internal divisions; b) it is highly unlikely that any sharing of emotion around such a football encounter would be transferred to other fields (in Bourdieu’s sense).

These presumptions about sport's contribution to social capital are founded in a belief about the wholemeal goodness of sport; e.g. that to take part one has to play fair, learn to comply with the rules and work with others. Sport thereby contributes to the shared norms 
component of social capital. And for some, sport is indeed about fair play, team spirit, respect and discipline, but for others it is associated with gamesmanship, winning at any price, topdown domination, exclusion, sexism, racism, homophobia, xenophobia... This is the dark side of sport that matches the dark side of social capital that Putnam (2000) acknowledges and then sets aside. There is another presumption about sport that is necessary if it is to contribute to social capital; that it is sociable and therefore participation in sport promotes social connectedness. In fact, some sports are lonely and demanding of time (especially when practised at a high level), and many sporting widows and widowers would certainly question the contribution to family cohesiveness. Clearly there is a need, at the very least, to differentiate sports and disaggregate ascribed characteristics.

Glover (2006, p. 360) challenged the uncritical approach of researchers who fail to appreciate 'the unique social/structural positions individual members occupy, so that the returns of social capital differ, too'. He suggested that a focus on the micro rather than the macro or meso helps to reveal how some are excluded (particularly on the basis of ethnicity and gender) from the benefits others enjoy. At that level Spaaij and Westerbeek (2010) report Dutch research showing that sport facilitates relatively few bridging links for minority ethnic groups, but other research suggests that the differentiation between levels may not be quite as Glover suggests. For example, at the meso level Numerato and Baglioni (2012) identified how sports associations might manipulate the trust generated through social capital to produce dark capital for commercial or political ends that may not be in the interests of those participating in the sport concerned. And the levels are rarely quite as distinct as they might at first appear: for example, de Luca (2013) has demonstrated that even in the apparently innocuous surroundings of a swimming club White power perpetuates White world views to maintain class and race-based privilege. Hylton (2008), among others, has stressed that, despite the success of many athletes from black and minority ethnic communities, sport 
stands accused of advantaging the social capital of white people. Nonetheless, organising around sporting enthusiasms, whether ethnically demarcated or not, almost imposes the formation of linking capital by obliging contact with different levels of the sporting hierarchy.

Different researchers seem to operate with different understandings of social capital, but this is not surprising as the concept is multi-faceted. We should not expect a simple answer to the question 'Does sport promote social capital?', nor even to an examination of whether it supports bonding at the expense of bridging. Certainly in terms of how sport might deliver different forms of social capital and any associated benefits, the processes seem to be complex. For example, in her research Walseth (2008) demonstrated how sports clubs in Norway can offer an environment for the development of social capital. However, while they allowed bridging between different immigrant groups they were less successful in bridging between immigrant and non-immigrant groups, or for that matter between social classes. Equally, Theebom et al. (2012) found that in the Netherlands members of ethnically mixed sports clubs bridged to learn about other ethnic groups, but it was those in ethnically separate sports that were more likely to help each other beyond the sporting context. So, having taken issue with other people's evasiveness on social capital, we need to be clear what aspects of social capital we are looking for here: we are interested in bridging capital that creates a new inter-cultural exchange and a new symbolic sense of shared identity between new migrant communities and other communities.

\section{Methodology}

This study was located in Leeds and was also the base for recruiting the research participants. Leeds is a diverse city and the home of established communities with a traditional colonial past. Leeds has a higher percentage of non-British residents (8\%) than the average in 
Yorkshire and the Humber region (5\%). Similarly the non-UK born population for Leeds (11\%) is higher than the Yorkshire and Humber average (8\%). Many of the more recent arrivals to Leeds do not bring a colonial legacy as the country with the highest number of migrants arriving in Leeds now come from Poland rather than the Asian sub-continent but never-the-less bear the mark of 'incomer', 'outsider', new 'migrant' (Migration Yorkshire 2012). These demographic changes contributed to the decision for our pilot study to focus on Polish European migrants as we explored whiteness, othering and racialization. In completing the pilot, for this study we elected to compare the experiences of the white European/Polish migrants with African migrants whose experiences of othering, inclusion and integration were more likely to be tempered by their blackness. ${ }^{1}$

We recruited our samples in community settings that included shops (especially specialist ethnic product retailers), streets, community facilities and community contacts. Interviews were conducted with 6 female and 8 male new migrants from Poland and 3 female and 5 males from sub-Sahara Africa. In establishing these groups we were mindful of their constructions in media and policy spaces. At the same time as we felt it necessary to work against uncritical uses of these constructions of social groups for this element of the study we worked with them in recognition of how they operate in the everyday. So rather than the groups constraining the study as labels we wanted to apply we used them as part of what we wished to explain (see Brubaker 2004). In the first instance the Africans had only their obvious blackness in common (they migrated from Cameroon, Uganda, Nigeria, Ghana and Zimbabwe) and the Polish contingent their whiteness and origin of travel. However the sample all had shared experience and knowledge of resettlement, international migration, racialisation, and leisure in common.

\footnotetext{
${ }^{1}$ We have tried to make the comparative distinction between European and African migrants, but in practice our European respondents are Poles.
} 
Using a mixed methodology we explored new migrant experiences. Our focus on racialisation, settlement, migration and leisure experiences meant that a broader quantitative approach would not have been as effective in elucidating the nuanced detail of these social processes (Stack \& Iwasaki 2009; Stodolska \& Walker 2007). We privileged the 'voice' of the new migrants and facilitated discussions across a range of language competencies through the use of mental mapping, photo-elicitation and qualitative interviews.

\section{Sports histories, sports growing up in their countries of origin}

All of our respondents reported some level of involvement with sports back in their countries of origin. Talking about sports and physical activity in their countries of origin allowed them to demonstrate to us the richness of their leisure lives before they came to the UK. Sports and leisure in the past were spaces where they could acquire and develop both social and cultural capital (Bourdieu, 1984; Putnam, 2000). Sports in their countries of origin demonstrated that they 'fitted in' to their communities and had high-enough status to be able to participate in a range of activities (Bourdieu, 1984). For some of them, this sports participation was shaped by their experiences in their childhood: taking part in forms of physical education, or playing informal sports with other children. Schools were (and are) obvious spaces for the construction of sporting capital.

Where they reported they took part in informal sports with other children growing up in their countries of origin, our respondents reflected on the communal, sociable element of such participation. For Lansana (Male, African), playing football was linked immediately with the memory of good times with friends: 'in Cameroon I used to play a lot of football and I used to love parties'. These informal sports brought a sense of communitas (Turner, 1969) for all our respondents, a sense of belonging and identity. Sports and other games and physical activities were connected to how they remembered their upbringing. The stories they 
told us about these informal sports were (re)constructions of community and belonging in their memory, representations of what they considered to be good times in their lives growing up, hanging around with friends, being a young person with few responsibilities, being close to family and sharing in the maintenance of Putnam's bonding capital. So, for example, Piotr (Male, European) told us that he 'was playing a lot of basketball, football as well', when he was back in Poland. This entailed a lot of time and resource from Piotr, but playing two sports did not make him feel constrained or pressured. These two sports, rather, were a natural part of his upbringing as a young Polish man, activities that provided a space for his own agency in defining his sense of belonging.

A small number of our respondents were involved in their countries of origin in organised, serious sports. These activities were what Stebbins (2011) calls serious leisure activities, which involved extensive and intensive amounts of time and resource. While there can be communicative rationality at work in such sports participation - for some people playing sports is a matter of free choice and agency - becoming involved in serious sport entails some surrender of freedom to the instrumental concerns of the sports systems that operate (McNamee, 1995; Spracklen, 2009). That is, participants in sports clubs and organised sports competitions are bound by the ideologies that constrain such activity. One submits to the rule of the coach and the manager, the club official and the referee, and one accepts the brutal logic at work: perform well, win things, obey the rules, and one can find economic (professional status and wages) and socio-cultural satisfaction (being part of the team/club, being adulated). Thus, the communicative leisure of informal play becomes the instrumental leisure of modern sport, where intrinsic satisfaction is replaced by extrinsic rewards. One of our respondents, Freddie (Male, African), told us about the role sports played in his earlier life, and the way they even shaped his decision to move to the UK: 
Oh, I didn’t just play football. I played serious competitive football. I played for the state, I played for the local government. I played table tennis as well. So I was an active sportsman...In fact I thought I would play professional football in England, coz I actually went for trials when I came in the UK in some clubs in England.

Freddie's youthful sporting career stands at the extreme of our respondents' engagement in sports before they came to the UK, and mirrors the stories told by many other young African men who travel abroad to try to 'make it' as a professional footballer (Poli, 2006). But the seriousness of his sports career was matched in many ways by two of the others in our study. We will mention the European respondent Dorota in the next section. Aga (Female, European) was also very active in her youth back home in Poland, and performed serious sport intensively and seemingly relentlessly. As she told us:

I was ice skating for 6 years, not professionally but quite intensive 6 days a week, September to June. I was a volunteer with autistic child. I am still in touch with this family, but the boy now is 19. I was a scout, I was a sailor, skiing, I've done a lot. We have amazing, massive lake district, and because I was an only child my parents were sending me on a lot of camps. Sport camps, sailing camps. So that's why I was meeting a lot of people and I never felt like an only child. And I was always trying a lot of sports.

Aga's parents are identified as key enablers and decision-makers in this young sportsas-career narrative. They had the right social and cultural capital that allowed them to give Aga a wide range of sports opportunities. They inculcated in her the discipline of serious sports as part of a broader diet of leisure and volunteering activities. It is interesting to see 
how Aga's memory conflates many distinct things into the one memory. She mentioned her time volunteering as a helper and carer alongside her almost daily ice-skating training regime, and her summers spent in various camps and engaging in outdoor activities. Clearly, Aga’s parents were insistent on her getting the best she could from the opportunities available to her. But they also had the money and networks that allowed her to enjoy these opportunities. Aga was a typical sporty youth who found belonging and identity through her many sports experiences, whether it was the instrumental leisure of her ice-skating practice or the more informal, playful activities in the camps.

Sports, games and physical activity, then, were integral to many of our respondents' memories of their upbringings, and for some of them, sports defined who they were.

\section{Sports in the UK}

Shinew et al. (2006, p. 405) say that:

the nature of how different groups interact in public leisure space and how they negotiate limited leisure resources will be important areas of inquiry. Given that communities and neighborhoods are becoming progressively diverse, leisure opportunities and events that help foster a sense of community and build social capital among residents will be important. In particular, a need exists to understand how leisure contributes to a sense of place and community in diverse neighborhoods including those communities that are forming and restructuring due to the changing social structure.

Sports should have been one of those leisure activities and spaces that provided a chance for our respondents from new migrant communities to find commonality with other 
social groups in Leeds. As our respondents all had memories and stories of engaging in some kind of sporting activities in their countries of origin, there should have been ample opportunities for them to translate the cultural capital they had 'earned' into social capital in their leisure lives in England (Bourdieu, 1984; Shinew et al., 2006). Leeds as a city is replete with sports facilities, from private sports clubs to leisure centres and sports programmes in the public sector - the local council has an active sports development unit, and there are policies to promote sports participation and physical activity specifically targeted at 'hard to reach groups' at a local and regional level. Nationally, policy-makers in sport have tried to increase numbers involved in sport, and sports governing bodies are evaluated for the success of their policies and plans on equality and diversity (Coalter, 2007, 2013). Leeds, for example, is the home of the national governing body of rugby league, which has won awards for its campaigns and strategies to tackle inequality and promote diversity (ww.rfl.uk.com). Despite this, there was little evidence that any of the policies or strategies had made a difference to our respondents. Even though they lived in a city that had a wide range of sports opportunities, they did not provide us with a great deal of evidence about any continuing sports participation when they told us about their leisure lives in the UK.

A minority of our respondents were still engaged in sports in the UK. Most of these mentioned to us fairly informal forms of physical activity that they undertook by themselves, for instance running in the park, cycling or swimming. None of these activities involved social interaction with anyone else, and although they are examples of a pure leisure choice, they did not offer any deeper communicative potential. A minority of the respondents still engaged in sports, however, were very active in that engagement, and were using sport as a form of communicative leisure. For these, their sports activity did provide a space for potentially increasing social and cultural capital through interactions with others: 
I started playing tennis here. I working with my friend who he play tennis, all his life. After he going back to Poland I play with Tom. I got a tennis racquet, tennis ball. Is nice to recreations (Arek, Male, European)

Arek’s tennis-playing might be held up as a success for sports participation as a means of increasing social and cultural capital, and providing belonging and identity that transcends symbolic boundaries. He did start to play tennis in the UK. But he was drawn to tennis by his fellow new migrant, who had played tennis himself back in Poland - and now he plays tennis with another Polish new migrant, his close friend Tomek. The best example of actively engaging in sports as a potentially inter-cultural space comes from the leisure experiences of Dorota and Aga. For Dorota, her experience of playing handball in Poland allowed her to find connections and make close friendships in England. Some of those friends were Polish, such as Aga, who also played handball - but there were others involved in handball from a range of nationalities. This could be counted on the side of the argument that sport builds bridging as well as bonding capital. Handball in this instance brought Dorota and Aga into leisure spaces where they mingled with a diverse group of individuals, including British players and a network of friends and followers. It could be argued that this demonstrates sport can be this leisure space that overcomes mistrust and prejudice, equalises inequalities of power, and allows individuals to find things in common with one another. Clearly, for Dorota and Aga as new migrants to the UK, handball was a way of making friends, crossing symbolic boundaries of belonging, feeling more included, while keeping in touch with the leisure practices of their lives in Poland.

\section{Concerns about sport}


Like many people in late modernity, our respondents found finding time and resources to engage in sustained leisure activities quite difficult. Despite that commonality of constrained leisure between our respondents and other residents of England, those who contributed to this research were engaged in wide ranging (sports, arts, tourism) and specialised (competitionlevel handball, amateur dramatics, capoeira) leisure activities. These activities were shaped by constraints commonly found in leisure research: time, family commitments, money and the need for 'leisure partners'. Many of our respondents told us about problems they had getting involved in sports and other forms of active leisure, and sustaining their youthful sports interests in Leeds and the UK.

There is too much stress here (laughs away)...back at home you have the freedom to do what you want to do at your own relaxed time but here you have to run and walk with time...it's too distressing. That's why most people don't have time for leisure activities...the bills are piling and piling so you're just thinking of where to get the next penny to pay the bills (Akos, Female, African)

Life in UK is kind of boring...life is so programmed and you're limited by time, movement, and other things (Jodie, Female, African)

What characterised these respondents' concerns about not having time and money to do sports and leisure was a critique of the working culture of England and a nostalgic reshaping of their 'home' cultures as being free from the instrumentality of modernity. It is interesting that Akos even uses the physical activity of running as a metaphor for the condition of British working life - the fact of working to establish new lives makes migrants too tired to think about doing anything active in their free time. For Jodie, the problem with 
British culture is its overly regimented and over-worked nature: the work-life balance, for her, has tipped too far. This regret about the obsession with money and work is of course partly a conflation of the facts of adult life with memories of fewer responsibilities when they were even a few years younger. But for our respondents, there is a real concern to work as much as possible to legitimise their status in the UK as much as possible, while justifying their migration to their family and friends back in their countries of origin through narratives of 'making it' and transfers of money. There is little chance for much inconsequential or communicative leisure.

For our European respondents from Poland, their time beyond work was sharply marked by intensive communication with friends and family in Poland, as well as the almost exclusive use of leave time away from work to visit Poland, facilitated by free movement within the EU and sufficient income to pay for (cheap) tickets. For our African respondents, the need to stay in touch was just as important, but travel back to their families and countries of origin was much more problematic.

Experiences of multiple aspects of mobility and migration mean constantly being confronted with learning about new places and spaces, which may limit capacity to 'integrate' and get to know neighbourhoods and form local attachments (Rutter et al., 2007, p. 67). In the USA, Li and Stodolska (2006) note that temporary residence status of Chinese students affected and constrained leisure. Many migrants not only undertake a major migration to come to the UK, but experience lives of ongoing transience and repeated movements. The UK may be a destination following time in other 'transit' or European countries. They may also experience considerable continuing mobility within the UK after arrival. Asylum seekers are dispersed on a no choice basis to areas of dispersal and it is likely that a substantial number move from this initial site. The need for financial security may necessitate travel or moving to find work. Some live in one place and travel great distances to 
get to jobs offered by an agency; others may move to live in another town or city, following work opportunities. Looking at the integration of refugees, Rutter et al. (2007, p. 113) found that those who had formed local attachments were more likely to feel they belonged in the UK and less likely to have hostile experiences in their neighbourhood. Time spent as an asylum seeker, and frequent residential mobility can impede integration and the intention or capacity to make local links (Cook, Dwyer \& Waite, 2011).

Rather than sport offering integration, some of our respondents specifically cite sports as forms of leisure that they have had problems with in the UK. That is, they told us that they do not play sports, especially those that involve playing with others (even where they have played them in their countries of origin). They have not been able to do sports, or have not been able to be interested in sports. This is often tied up with the wider issue of not having the time (or resource, or energy) to do any sustained leisure activity. But there are other factors at work.

Kwame (Male, African): In Ghana we also have lots of activities like playing football with friends.

Interviewer: Did you play football in Ghana?

Kwame: Yeah I did. But here I can’t because you wouldn’t even think of looking for a park or finding people to go and play with. There are no people to organize for football. There is no organization...for you to play football you have to have people to play with and at least where to play, what times, so it requires a bit of organisation.

There are hundreds of open-age men's football clubs in Leeds, ranging from teams that compete in indoor leagues and park leagues to clubs that operate essentially as semiprofessional businesses in leagues immediately below the professional Football League. 
There are football development officers in the city and the region with policies and plans to promote football, and teams and clubs built around minority ethnic communities. There are many public parks where it is possible to kick a football around with, to quote The Fast Show's Ron Manager, ‘jumpers for goalposts'. What Kwame means by not having 'people to go and play with' are people that he knows and he trusts to be playing football alongside. His desire to play football is limited by the lack of football players in his immediate circle of acquaintances, and his fear to attempt to try to go to a place where somebody is playing football. He does not have the right social and cultural capital to become a footballer in Leeds, so there is little chance to use the sport to build a sense of inter-cultural community, identity and belonging.

\section{Leisure, identity and community}

While sports and organised forms of physical activity do not feature centrally in the experiences of our respondents, they do take part in a wide range of other leisure activities in a range of leisure spaces. We have discussed their leisure activities and spaces in other published research (Long, Hylton, Lewis, Ratna \& Spracklen, 2011), but it is necessary to return to the wider published findings here to contrast this part of our research project with this specific analysis of sports. What we found was that all our respondents in the new migrant communities had rich and meaningful leisure lives, and found time, money and space to do things in their free time that were communicative and inconsequential. This urge to do something that gave them a sense of identity, community and belonging, as well as pleasure and satisfaction, found them reporting all kinds of leisure. They all spent time with families and friends, they socialised on-line, they watched television and films, and were involved with churches. Many of the Polish respondents reported leisure activities that brought them 
into spaces where they did interact with British people, work colleagues or others, enjoying their free time in the particular leisure space.

Liz (Female, European): We just going looking for place where we can dance. Went to few places, no one dancing. That's what we wanted to do - to dance. After band it was DJ. It was nice music. So we danced and we came back home and our legs was killing us.

Interviewer: Unusual - last time you said you weren’t keen on going out with people from work?

Liz: I did like them, but work is work and my private life is my private life, and I don’t really want to mix them. If I've got a few friends - but not all group. Some people you just treat them professional. You just don't want to socialise with them out of work.

Such leisure activities are examples of Roberts’ (2011) inconsequentiality. Liz just wants to dance and have fun with her close friends, and there is no hidden purpose in what she does (even if the consequence is a building of bonding capital with her friends, and cultural capital around knowing which clubs in Leeds she can go to and do the things she wants to do). In doing this kind of leisure, Liz is demonstrating her ability to think and act communicatively about her leisure (Spracklen, 2009). But as we have discussed elsewhere, such communicative choices about leisure, the agency at work in building capital, identity and community, is constrained among all our respondents. They all struggle to generate enough resources to do the things they want to do in their leisure time, and all the choices they make are limited by the hegemony of neo-liberalism in England that shapes reward patterns and asserts what is appropriate behaviour (Wilkinson \& Pickett, 2009). As migrants, 
they are bound by the networks of obligation to families in their countries of origin, as well as bound by the prejudices that keep them Othered in England (Long \& Hylton, 2002). For the African respondents there is an additional constraint on their leisure that is associated with their ethnicity and their fear and experiences of additional prejudice. The social and cultural capital they have in their countries of origin is harder to use in England than that of the white European migrants from Poland.

\section{Discussion and conclusion}

The evidence from our research questions the simplistic claim that new migrant communities only need to do organised sport to become included in the community and locality around their new home. Our respondents since arriving in England they have changed the way they do things in their leisure time. They do get communicative value from doing leisure inconsequentially, but their leisure choices remain constrained by the inequalities of late modernity (Bramham, 2006). The example of sports participation that emerged from our research indicates a reduction in activity after migration and a longing to do sports in England (to that extent at least they do want to 'fit in'), but a fear and inability to do so. Of course, most people give up sports as they get older, but we are persuaded that there is something more afoot here. Bonding and bridging capital, where they appear, are more likely to be generated from other leisure activities. Where our respondents do sports, it is mainly alone or with others from their new migrant communities, so they do not build bridging capital.

It has been argued by some sociologists of sport and leisure that sports can play a role in building forms of capital and belonging that are inclusive of people from minority ethnic communities and new migrant communities. Vermeulen and Verweel (2009) claim that sports participation has a moral and social good that can be transformed into a broader form of inclusion for minority ethnic individuals in modern societies. In their research on sports 
participation among minority ethnic groups in Holland they conclude (Vermeulen \& Verweel, 2009, p. 1216):

participation in and through sport can help individuals to develop competence in the sometimes subtle and situational processes of inclusion and exclusion; and to learn that where someone is included, others are excluded... Sport does provide ways to be included, and to attain (self) recognition and self-esteem (in short, an identity) by being recognized as skilful in sport for instance.

They then go on to consider the potential to transform this into other forms of capital, observing that:

an identity that is constructed through sport is not simply a kind of commodity that can be 'handed over' to other domains of life... So, work has to be done and conditions are to be created in order to be included in other domains than sport. The contribution of sport to social capital and social integration is not to be assessed (nor to be achieved) by putting these concepts in causal chains, but by gaining insight in the intricacies and complexities of bonding and bridging through sport as identity work. (ibid.)

We agree with them that the contribution of sport participation to social capital and social inclusion/integration among minority ethnic and new migrant communities is not something that can be assumed unproblematically. Walseth's $(2006,2008)$ research on sports participation among young minority ethnic women in Norway shows that those young women involved in the sports did feel they had a sense of belonging. However, the bonding 
capital that emerges from playing a team sport does not mean that bridging capital necessarily follows from sports participation. As she explains (Walseth, 2008, p. 15):

the large amount of time spent together with teammates and having an 'enemy' (in the case of team sports: an opposing team) can be important for the production of a collective 'we'... Having an enemy can help create social capital. Thus, one might argue that the characteristic features of team sports enable team sports to be wellsuited arenas for the development of social capital... The sports clubs in this study play a limited role as an arena for bridging social capital across social class and the immigrant/non-immigrant divide.

Walseth's work shows that sports can play a positive role in building social and cultural capital. They do provide a way of creating belonging and identity. But their usefulness as examples of inconsequential or communicative leisure are limited by the instrumental hegemonies that created sports in the first place (Spracklen, 2009, 2011, 2013). Sports do the work of hegemony by othering and excluding. Modern sports are generally leisure activities that propagate elitism, exclusion, a neo-Darwinian 'survival of the fittest' and a heteronormative, hegemonic masculinity (Connell, 1995). We are not suggesting that potential does not exist, just that, contrary to the aspirations of its advocates, sport is more likely to reaffirm otherness and in so doing assign people to functionalist roles. Modern sports are used to create distinction and status, and no amount of social capital can replace the economic capital invested in many types of sport, which excludes on the basis of class. We agree with Walseth's scepticism about the ability for sport to unproblematically build bridging capital that might lead to a truly intercultural dialogue and a truly inclusive, new public sphere. A more critical approach to the use of sport in promoting inclusion and 
belonging among new migrant communities is needed, and a more sceptical response to the claims that doing sport will create the bridging capital needed to create a better society.

\section{References}

Blackshaw, T. (2010). Leisure. London: Routledge.

Bourdieu, P. (1984). Distinction: A social critique of the judgement of taste. London: Routledge.

Bramham, P. (2006). Hard and disappearing work: Making sense of the leisure project. Leisure Studies, 25(4), 379-390.

Brubaker, R. (2004). Ethnicity without groups. London: Harvard University Press.

Coalter, F. (2007). Sports clubs, social capital and social regeneration: 'Ill-defined interventions with hard to follow outcomes'? Sport in Society, 10(4), 537-559.

Coalter, F. (2010). Sport-for-development: Going beyond the boundary? Sport in Society, 13(9), 1374-1391.

Coalter, F. (2013). Game Plan and the spirit level: The class ceiling and the limits of sports policy? International Journal of Sport Policy and Politics, 5(1), 3-19.

Connell, R. (1995). Masculinities. Cambridge: Polity. 
Cook, J., Dwyer, P., \& Waite, L. (2011). ‘Good relations’ among neighbours and workmates? The everyday encounters of Accession 8 migrants and established communities in urban England. Population, Space and Place, 17(6), 727-741.

de Luca, J. (2013). Submersed in social segregation: The (re)production of social capital through swim club. Journal of Sport and Social Issues, 37(4), 340-363.

Denham, J. (2001). Building cohesive communities: A report of the ministerial group on public order and community cohesion. London: Home Office.

Froissard, S. (2010). Integrating migrants through sport: Untapped potential. Foreword in W. Gasparini and A. Cometti, Sport facing the test of Cultural Diversity, Strasbourg: Council of Europe.

Gasparini, W., \& Cometti, A. (2010). Sport facing the test of cultural diversity. Strasbourg: Council of Europe.

Glover, T. (2006). Toward a critical examination of social capital within leisure contexts: From production and maintenance to distribution. Leisure/Loisir, 30(2), 357-367.

Guiberneau, M. (2013). Belonging: Solidarity and division in modern societies. Cambridge: Policy. 
Habermas, J. (1984). The theory of communicative action, volume one: Reason and the rationalization of society. Cambridge: Polity.

Habermas, J. (1987). The theory of communicative action, volume two: The critique of functionalist reason. Cambridge: Polity.

Halpern, D. (2005). Social capital. Cambridge: Polity.

Hylton, K. (2008). Race equality and sport networks. In M. Nicholson and R. Hoye (Eds), Sport and social capital (pp. 257-283). Oxford: Elsevier.

Li, M. Z., \& Stodolska, M. (2006). Transnationalism, leisure, and Chinese graduate students in the United States. Leisure Sciences, 28(1), 39-55.

Lin, N. (2001). Social capital: A theory of structure and action. London: Cambridge University Press.

Lin, N (2006). A network theory of social capital. In D. Castiglione, J. van Deth and G. Wolleb (Eds.) The handbook of social capital (pp. 50-59). Oxford: Oxford University Press.

Long, J. (2012). Integration and Othering: The experiences of Black and White new migrants. Paper presented at the British Sociological Association annual conference, University of Leeds, April 2012. 
Long, J., \& Hylton, K. (2002). Shades of white: an examination of whiteness in sport. Leisure Studies, 21(2), 87-103.

Long, J., Hylton, K., Lewis, H., Ratna, A., \& Spracklen, K. (2011) Space for inclusion? The construction of sport and leisure spaces as places for migrant communities. In A. Ratna and B. Lashua (Eds.) Community and inclusion in leisure research and sport development (pp. 33-53). Eastbourne: Leisure Studies Association.

McNamee, M. (1995). Sporting practices, institutions, and virtues: A critique and a restatement. Journal of the Philosophy of Sport, 22(1), 61-82.

Maxwell, H., \& Taylor, T. (2010). A culture of trust: Engaging Muslim women in community sport organizations. European Sport Management Quarterly, 10(4), 465-483.

Migration Yorkshire (2012). Leeds local migration profile: Summary document. Available at http://www.migrationyorkshire.org.uk/userfiles/attachments/pages/609/leeds-lmpsummarynov2012.pdf (accessed 16 January 2014).

Numerato, D., \& Baglioni, S (2012). The dark side of social capital: An ethnography of sport governance. International Review for the Sociology of Sport, 47(5), 594-611.

Organisation for Economic Cooperation and Development (2001). The wellbeing of nations: The role of human and social capital. Paris: OECD. 
Poli, R. (2006). Africans' status in the European football players’ labour market. Soccer and Society, 7(2-3), 278-291.

Putnam, R. D. (2000). Bowling alone: The collapse and revival of American community. New York: Simon \& Schuster (Touchstone).

Roberts, K. (2004). The leisure industries. Basingstoke: Palgrave.

Roberts, K. (2011). Leisure: The Importance of being inconsequential. Leisure Studies, 30(1), 5-20.

Rojek, C. (2010) The labour of leisure. London: Sage.

Rojek, C. (2013). Is Marx still relevant to the study of leisure? Leisure Studies, 32(1), 19-33.

Rutter, J., Cooley, L., Reynolds, S., \& Sheldon, R. (2007). From refugee to citizen, 'standing on my own two feet': A research report on integration, 'Britishness' and citizenship. London: Refugee Support.

SDP/IWG (2006). Sport for development and peace: From practice to policy. Toronto: SDP/IWG.

Shinew, K. J., Stodolska, M., Floyd, M., Hibbler, D., Allison, M., Johnson, C., \& Santos, C. (2006). Race and ethnicity in leisure behavior: Where have we been and where do we need to go? Leisure Sciences, 28(4), 403-408. 
Siisiäinen, M. (2000). Two concepts of social capital: Bourdieu versus Putnam. Paper presented at the ISTR Fourth International Conference 'The Third Sector: for what and for whom?’ Trinity College Dublin, July 2000. Available at http://c.ymcdn.com/sites/www.istr.org/resource/resmgr/working_papers_dublin/siisiainen.pdf (accessed 15 November 2013).

Spaaij, R. and Westerbeek, H. (2010). Sport business and social capital: A contradiction in terms? Sport in Society, 13(9), 1359-1376.

Spracklen, K. (2009). The meaning and purpose of leisure: Habermas and leisure at the end of modernity. Basingstoke: Palgrave Macmillan.

Spracklen, K. (2011a). Dreaming of drams: Authenticity in scottish whisky tourism as an expression of unresolved Habermasian rationalities. Leisure Studies, 30(1), 99-116.

Spracklen, K. (2011b). Constructing leisure: Historical and philosophical debates. Basingstoke: Palgrave Macmillan.

Spracklen, K. (2013). Whiteness and leisure. Basingstoke: Palgrave Macmillan.

Spracklen, K., \& Spracklen, B. (2012). Pagans and Satan and goths, oh my: Dark leisure as communicative agency and communal identity on the fringes of the modern goth scene. World Leisure Journal, 54(4), 350-362. 
Stack, J., \& Iwasaki, Y. (2009). The role of leisure pursuits in adaptation processes among Afghan refugees who have immigrated to Winnipeg, Canada. Leisure Studies, 28(3), 239259.

Stebbins, R. (2011). Serious Leisure: A perspective for our time. Piscataway: Transaction Publishers.

Stodolska, M., Kimberly, J. S., Floyd, M. F., \& Walker, G. J. (2013). Race, Ethnicity, and Leisure. Champaign: Human Kinetics.

Stodolska, M., \& Walker, G. (2007). Ethnicity and leisure: Historical development, current status, and future directions. Leisure/Loisir, 31(1), 3-26.

Theeboom, M, Schaillée, H., \& Nols, Z. (2012). Social capital development among ethnic minorities in mixed and separate sport clubs. International Journal of Sport Policy and Politics, 4(1), 1-21.

Turner, V. (1969). The ritual process: Structure and anti-structure. Ithaca: Cornell University Press.

United Nations (2005). International year of sport and PE. Available at http://www.un.org/sport2005/a_year/mill_goals.html (Accessed 15 January 2014).

United Nations (2013). UN Office on Sport for Development and Peace annual report 2012. Geneva: United Nations. 
Vermeulen, J., \& Verweel, P. (2009). Participation in sport: Bonding and bridging as identity work. Sport in Society, 12(9), 1206-1219.

Walseth, K. (2006). Young Muslim women and sport: The impact of identity work. Leisure Studies, 25(1), 75-94.

Walseth, K (2008). Bridging and bonding social capital in sport: Experiences of young women with an immigrant background. Sport, Education and Society, 13(1), 1-17.

Watson, B., \& Scraton, S. J. (2013). Leisure studies and intersectionality. Leisure Studies, 32(1), 35-47.

Wilkinson, R., \& Pickett, K. (2009). The spirit level: Why equality is better for everyone. London: Penguin. 